\title{
CORRIGENDUM
}

\section{Repeated administration of an acetylcholinesterase inhibitor attenuates nicotine taking in rats and smoking behavior in human smokers}

RL Ashare, BA Kimmey, LE Rupprecht, ME Bowers, MR Hayes and HD Schmidt

Translational Psychiatry (2017) 7, e1072; doi:10.1038/tp.2017.46; published online 28 March 2017

Correction to: Translational Psychiatry (2016) 6, e713; doi:10.1038/ tp.2015.209; published online 19 January 2016

The authors noticed that an omission was made in the Acknowledgements section. The omitted data appear below.

This project was partially funded by a grant from the Pennsylvania Department of Health.

\begin{abstract}
This work is licensed under a Creative Commons Attribution 4.0 International License. The images or other third party material in this article are included in the article's Creative Commons license, unless indicated otherwise in the credit line; if the material is not included under the Creative Commons license, users will need to obtain permission from the license holder to reproduce the material. To view a copy of this license, visit http://creativecommons.org/licenses/ by/4.0/
\end{abstract}

(c) The Author(s) 2017 